\title{
Locomotor performance of sand lizards (Lacerta agilis): effects of predatory pressure and parasite load
}

\author{
Anna Ekner-Grzyb • Zofia Sajkowska • Krzysztof Dudek • \\ Monika Gawalek • Piotr Skórka • Piotr Tryjanowski
}

Received: 2 January 2013 /Revised: 10 April 2013 /Accepted: 25 April 2013 /Published online: 12 May 2013

(C) The Author(s) 2013. This article is published with open access at Springerlink.com

\begin{abstract}
Locomotor performance affects foraging efficiency, predator avoidance and consequently fitness. Agility and speed determine the animal's social status and reflect its condition. In this study, we test how predatory pressure and parasite load influences locomotor performance of wild specimens of the sand lizard Lacerta agilis. Animals were chased on a 2-metre racetrack. Lizards with autotomy ran significantly faster than lizards with an intact tail, but there was no significant difference in running speed between individuals with fresh caudal autotomy and regenerated tails. Parasite presence and load, age and sex had no significant effect on speed. Our results indicate that autotomy either alters locomotory behaviour or that individuals with autotomised tails were those that previously survived contact with predators, and therefore represented a subgroup of the fastest individuals. Therefore, in general, predatory
\end{abstract}

\footnotetext{
A. Ekner-Grzyb $(\bowtie)$

Department of Behavioural Ecology, Adam Mickiewicz

University, Umultowska 89,

61-614 Poznan, Poland

e-mail: anna.ekner@gmail.com

Z. Sajkowska

Laboratory of Biological and Natural Education, Adam

Mickiewicz University, Umultowska 89,

61-614 Poznan, Poland

K. Dudek $\cdot$ P. Skórka $\cdot$ P. Tryjanowski

Institute of Zoology, Poznań University of Life Sciences, Wojska Polskiego 71C,

60-625 Poznan, Poland

M. Gawałek

Laboratory of Neurobiology, Poznań University of Life Sciences,

Wojska Polskiego $71 \mathrm{C}$,

60-625 Poznan, Poland
}

pressure but not parasites affected locomotor performance in lizards.

Keywords Tail loss $\cdot$ Anti-predator behaviour · Ixodes ricinus $\cdot$ Caudal autotomy $\cdot$ Running speed $\cdot$ Lacerta agilis

\section{Introduction}

Locomotor performance is of primary importance for lizard survival while escaping (Husak 2006). Successful escape from predators, foraging and mating ability may be strongly dependant on individual's capacity to accelerate or to achieve a certain speed (Tsuji et al. 1989; Clobert et al. 2000; Vanhooydonck and Van Damme 2003). Being such an important feature, running speed in lizards is also commonly used as a predictor of animal's health, body condition and potential survival under predatory pressure (Hertz et al. 1988; Huey et al. 1990; Jayne and Bennett 1990).

The locomotor performance of lizards is influenced by many factors, such as tail length, body mass, snout-vent length (SVL) (Du et al. 2005; Lin and Ji 2005; Vervust et al. 2008; Li et al. 2011) and caudal autotomy (Martin and Avery 1998; Chapple and Swain 2002; Shine 2003; Chapple et al. 2004; Cooper et al. 2009). Tail autotomy is a widespread predator avoidance strategy among lizards (Arnold 1988), providing a visual stimulus for the predator to focus its attention on the tail and increase the chances of the lizard's escape (Bateman and Fleming 2009; $\mathrm{Lu}$ et al. 2010). However, autotomy may also have negative consequences, such as lower social status (Fox et al. 1990), smaller territory size (Salvador et al. 1995) or low reproductive success (Martín and Salvador 1993). In many lizard species, the tail is an important organ for lipid storage, which is mainly concentrated in its proximal part (Lin and Ji 2005), and lipids 
are the main source of energy for many lizard species (Doughty et al. 2003). Therefore, autotomised lizards may be more vulnerable to predation than lizards with intact tails (Dial and Fitzpatrick 1984; Wilson 1992). Autotomy may also modify locomotor performance in various ways. Most of the previous studies showed that caudal autotomy often impaired the sprint performance in lizards (Martin and Avery 1998; Shine 2003; Chapple et al. 2004; Cooper et al. 2009). Tailless individuals may lose equilibrium, thus leading to irregularities of trajectories of the central point of the pelvis during movements (Martin and Avery 1998). However, other research has demonstrated that tailless lizards run faster (Daniels 1983; Brown et al. 1995) or did not differ from the intact ones (Huey et al. 1990; Kelehear and Webb 2006; Lu et al. 2010). The effect of caudal autotomy on locomotor performance seems to be species specific (Van Damme and Vanhooydonck 2001) and depends on the amount of tail loss and the time since autotomy (Downes and Shine 2001; Chapple and Swain 2002; Lin and Ji 2005).

The effect of parasites on locomotor performance is barely understood. Parasites strongly negatively affect lifehistories (review by Møller 1997), fitness (review by Møller 1990) and survival (Sorci et al. 1996) of their host. Further negative effects include physiological, ecological and behavioural alternations of the host animal organism (Schall et al. 1982; Main and Bull 2000; Reavis and Barrett 2001; Bouma et al. 2007; Fenner and Bull 2008; Martín et al. 2008). A few published results on parasites in lizards showed that Shingleback (Tiliqua rugosa) infected with the haemogregarine blood parasite Hemolivia mariae had smaller home ranges (Bouma et al. 2007), and parasitized females of the common lizard Zootoca vivipara had lower activity levels (Sorci et al. 1996). The common lizards infected with haemogregarines (Oppliger et al. 1996) were characterised by slower running speed. On the other hand, malaria caused lizards to have better endurance, but did not influence their speed during sprints (Schall et al. 1982; but see Schall 1990). Sorci et al. (1994) suggested that parasites may not only modify locomotor performance of their lizard hosts but also of their offspring. Some parasites caused weight loss (Lavoie et al. 2000), which may contribute to greater capacity for rapid speed (Cooper et al. 1990).

One of the most common worldwide parasites that live on lizards are ticks (Barnard and Durden 2000). Despite a few studies which indicated a possible positive correlation between tick load and some life history traits of the sleepy lizard (T. rugosa), such as body mass and mating probability (Bull and Burzacott 1993), the majority of authors have reported a negative impact of ticks on their hosts (Lehmann 1993). Lizard infested with ticks may have slower running speeds, lower endurance and consequently different home range than individuals without ticks (Main and Bull 2000). Lizards with ticks may also have reduced activity and a lower chance of finding suitable food resources or refuges (Main and Bull 2000). The negative effects of ticks in relation to the lizard's locomotor performance may be manifested in several ways: (1) pathogen transmission, i.e. Borrelia burgdorferi s.l. and Anaplasma spp. (Ekner et al. 2011), which, among others, are also human infecting bacteria, affecting nervous and immunological systems (Svetina et al. 1999; Dumler et al. 2001), (2) lower haemoglobin concentration leading to anaemia in their hosts (Oppliger et al. 1996; Schall et al. 1982; Schall 1990; Wikelski 1999) and (3) mechanical alternations to lizard's mobility by altering mechanisms of running, by occupying joints, mostly around forelimbs (Bauwens et al. 1983; Fig. 1).

The sand lizard Lacerta agilis is one of the most abundant lizard species across Europe (Sura 2003). However, according to our knowledge, there have been only a few studies on its locomotor performance (Nemes 2002), and none of them relates to the problem of how animal's performance is affected by body condition, tick load and former contacts with predators. To date, only a few studies have tested the effect of parasites on lizard running speed (Main and Bull 2000). Moreover, recent studies on the lizard's movement have only been done under laboratory conditions. Therefore in our experiment, we have only included wild caught lizards soon after they have been captured in the field, which provided the best reflection of the natural variation in the tick load and autotomy on the running performance. We predict that parasites should alter the locomotor performance of sand lizards.

We hypothesised that parasites should alter the locomotor performance of sand lizards. In the present study, we investigated the influence of the castor bean tick Ixodes ricinus and autotomy on running speed of L. agilis. Moreover, we also tested for sex and age differences on locomotor performance of the lizards when controlled for body temperature.

\section{Materials and methods}

Study area and the species studied

The study was carried out in April-June in 2009 and 2010 in the Barycz valley, in Poland $\left(51^{\circ} 34^{\prime} \mathrm{N}, 17^{\circ} 40^{\prime}\right.$ E, elevation

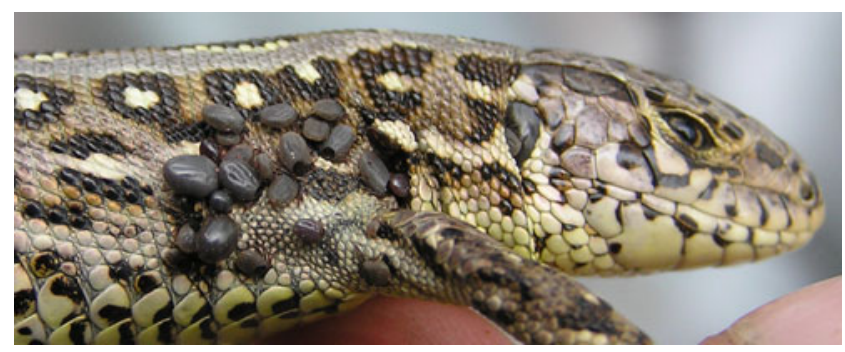

Fig. 1 Ticks, I. ricinus concentrated around the forelimb joints of a sand lizard, Lacerta agilis 
$110-170 \mathrm{~m}$ ). This study area is characterised by extensively farmed land with a varied mosaic of arable fields, meadows, small woodlots and scattered trees and shrubs of different ages, dominated by white willow (Salix fragilis), silver birch (Betula pendula), black poplar (Populus nigra) and Scots pine (Pinus silvestris). It contains both dry sandy areas and moist areas (for details see Antczak et al. 2004).

L. agilis is a short-legged, rather robust, small to medium sized lizard (ranging from 121 (100 for juveniles) to $235 \mathrm{~mm} \mathrm{SVL}$ ) from the family Lacertidae (Juszczyk 1987). It is a ground-dwelling and strongly diurnal species with one of the widest distribution ranges of all reptiles (Bischoff 1984). In the study area, L. agilis is a common species, and an average of 0.37 individuals were noted on a $200 \mathrm{~m}$ transect route (Ekner et al. 2008).

\section{Experimental procedures}

Lizards were captured using special herpetology nets (fabric net attached to a metal circle on the end of a metal stick) or by hand. Animals were placed separately in cotton bags to avoid interaction between them. They were kept for $1 \mathrm{~h}$ before the experiment (Vervust et al. 2008). Pregnant females were excluded from the experiment because too few were caught. Afterwards, lizards were chased on a 2metre racetrack, consisting of a floor (made of a porous surface to ensure appropriate grip), three lateral walls and a shaded shelter at the end of the track, which was supposed to induce the reptiles to run in that direction (Farley 1997). Animals were placed on the track and were encouraged to run by hand tapping on the floor, just behind the tail (PérezTris et al. 2004). To avoid experimenter effects, only one person (A.E.G.) ran the experiment. We treated all individuals in the same way we chased all of them, not only those which did not want to run. The experiment was filmed using a digital camera, placed on a tripod behind the simulated trap. The recording was analysed using the AxioVision (Zeiss) computer programme.

We analysed running speed of the lizards. Most lizards stopped during running, and those with more than three stops during this phase were omitted from analysis. Where stops occurred, we averaged running speed between the stops.

Immediately after the experiment, cloaca temperature was checked, using a pyrometer. Next, lizards were aged (adult, sub-adult and juvenile), sexed and measured (SVL). Animals were examined for the presence of ticks, which were removed with forceps and stored in $70 \%$ ethanol. Next, in a laboratory, ticks were identified to species and aged using a binocular microscope, according to Siuda (1993). All were identified as I. ricinus. Autotomy was checked for tail length; original or regenerated was measured.
To avoid pseudoreplication, lizards were permanently marked using medical cautery units (Ekner et al. 2011), and hence each individual was used only once in the experiment.

\section{Statistics}

General linear mixed models (GLMM) were built to test the effects of age, sex, autotomy (comparison of lizards with and without tail autotomy), tick presence and load (square root transformed) and cloacal temperature on mean lizard speed. Tick presence was an explanatory variable, coded as 0 (ticks absent) and 1 (at least one tick present), and it was tested in a separate model from that in which tick load (number of ticks per lizard) was analysed. In the latter model, only lizards with at least one tick were included. Because the sex of sub-adult and juvenile lizards could not be determined during this study, three different GLMM were built. The first model contained all the factors above except sex. In the second model, we compared the effect of the factors above on mean speed, ignoring age of lizards but including the effect of sex. Because the effects of age and sex were non-significant in both models, we joined these variables into one categorical variable (with the following levels: adult females, adult males, sub-adults and juveniles) and included it in the final GLMMs. We present results of these latter models only because their results were convergent with the former ones. In each model, we included interaction terms between the categorical and continuous variables. We removed all interaction from the final model because none were statistically significant. In every model, site identity (place where lizards were captured and tested) was included as a random effect.

Statistical analyses were performed using JMP 9 and SPSS 18.0 PL software. Data are summarised as means with a $95 \%$ confidence limit for binary (presence-absence) data and \pm standard deviation or standard error otherwise.

\section{Results}

We analysed 142 L. agilis lizards (26 females, 41 males, 42 sub-adults and 33 juveniles). One hundred and two individuals had an intact tail (71.8\%, 95\% CL 63.7-79.1), and 40 were autotomised (28.2\%, $95 \%$ CL 21.0-36.3). Among the autotomised individuals, 10 had fresh autotomy $(25.0 \%$, $95 \%$ CL: $12.7-41.2)$, and 30 had regenerated tails (75.0\%, $95 \%$ CL 58.8-87.3).

In total, 341 ticks were found in 55 of the $142(38.7 \%$, $95 \%$ CL 30.7-47.3) examined lizards. On average, there were $(\mathrm{x} \pm \mathrm{SD}) 2.4 \pm 7.1$ ticks per host. The maximum number of ticks on a lizard was 66 (on an adult male). Most parasites were concentrated around axilla (Fig. 1). 
Table 1 Statistical results from a general linear mixed model examining the effects of age, sex, tail autotomy (comparison of individuals with versus without tail autotomy), tick presence and cloacal temperature on mean speed of the sand lizard (Lacerta agilis)

Fixed effect tests

\begin{tabular}{lllll}
\hline Source & DF numerator & DF denominator & F & P \\
\hline Age sex & 3 & 53.6 & 0.34 & 0.797 \\
Autotomy & 1 & 57.2 & 5.36 & $0.024^{*}$ \\
Ticks' presence & 1 & 55.1 & 0.05 & 0.823 \\
Temperature & 1 & 21.0 & 0.58 & 0.455 \\
\hline
\end{tabular}

Autotomy positively influenced the speed of L. agilis (Table 1, Fig. 2). There were no significant effects of tick presence, tick load, cloaca temperature, age or sex on speed (Tables 1 and 2). When we compared lizards with fresh caudal autotomy and those with regenerated tails, we found no statistical difference in the mean speed between these two groups (Table 3, Fig. 2). There was also no statistical difference in tail length between lizards with autotomised (fresh or regenerated) and intact tails (mean \pm SD; 88.5 \pm 40.7 and $77.8 \pm 27.6$, respectively; Mann-Whitney $U$ test, $\mathrm{Z}=-1.31$, asymptotic significance (two-tailed) $=0.189$ ). There were no significant effects of SVL on speed, in both cases.

\section{Discussion}

Locomotor performance is important for lizards, when they are escaping from predators or when hunting (Clobert et al. 2000; Vanhooydonck and Van Damme 2003). The results of our study indicate that the lizards with autotomy ran faster. The results are similar to those obtained in previous research (Daniels 1983; Brown et al. 1995), which was probably a result of the marginal role that body part plays in movement

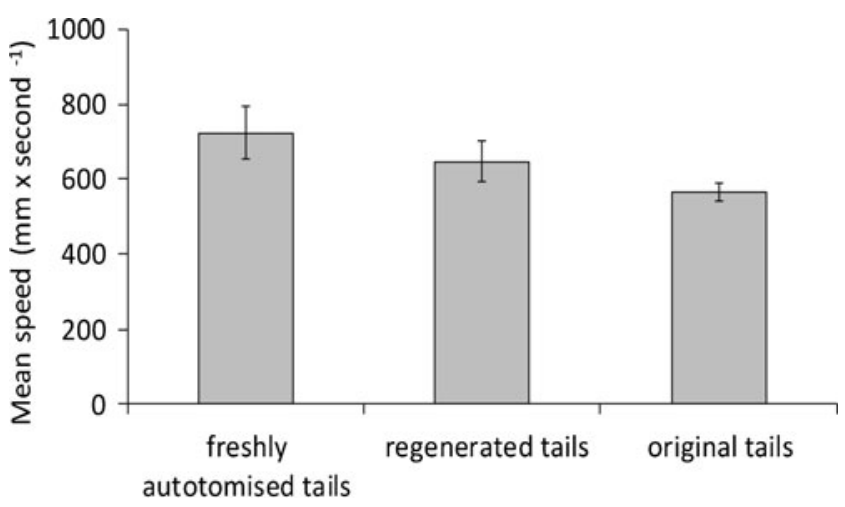

Fig. 2 Mean speed of lizards with freshly autotomised tails, regenerated tails and original tails. Means with standard errors are presented
Table 2 Statistical results from a general linear mixed model examining the effects of age, sex, autotomy (comparison of individuals with and without tail autotomy), tick load and cloacal temperature on mean sand lizard (Lacerta agilis) speed-results run with data on lizards with at least one tick

Fixed effect tests

\begin{tabular}{lllll}
\hline Source & DF numerator & DF denominator & F & P \\
\hline Age sex & 3 & 14.1 & 0.13 & 0.938 \\
Autotomy & 1 & 13.2 & 0.85 & 0.372 \\
Tick load (Sqrt) & 1 & 15.9 & 1.88 & 0.189 \\
Temperature & 1 & 13.9 & 0.07 & 0.802 \\
\hline
\end{tabular}

in some species, e.g. the frog-eyed sand gecko, Teratoscincus scincus (Lu et al. 2010). Locomotor performance could also be influenced by the length of the original tails, where shorter tail increases the running speed (Garland 1985; Li et al. 2011). The higher speed of short-tailed individuals could also be a result of their lower body weight (Martin and Avery 1998) or lower ground contact while running (Daniels 1983). However, in our study, most (75\%) autotomised lizards had already regenerated tails, and the length of the tails of lizards with autotomy (fresh or regenerated) did not differ from the intact individuals. Moreover, when we compared lizards with fresh and with regenerated autotomy, there was no difference in speed between them. This interesting result suggests that, in this case, tail length, or other factors mentioned above, did not influence locomotor performance, but the effect of autotomy is important. Our findings support a previous study on the common wall lizard, Podarcis muralis, where individuals with regenerated tails ran faster than individuals with intact tails (Brown et al. 1995). However, in the metallic skink Niveoscincus metallicus and the Cape dwarf gecko Lygodactylus capensis, no differences were noted between the locomotor performance of the individuals with original or regenerated tails (Chapple and Swain 2002; Medger et al. 2008).

Table 3 Statistical results from a general linear mixed model examining the effects of age, sex, tail autotomy (comparison of individuals with fresh caudal autotomy versus regenerated tails), tick load and cloaca temperature on mean speed of the sand lizard (Lacerta agilis)

Fixed effect tests

\begin{tabular}{lllll}
\hline Source & $\begin{array}{l}\text { DF } \\
\text { numerator }\end{array}$ & $\begin{array}{l}\text { DF } \\
\text { denominator }\end{array}$ & F & P \\
\hline Age sex & 3 & 6.32 & 0.24 & 0.866 \\
$\begin{array}{l}\text { Autotomy } \\
\text { (regenerated/fresh) }\end{array}$ & 1 & 8.07 & 0.00 & 0.963 \\
$\begin{array}{l}\text { Tick load (Sqrt) } \\
\text { Temperature }\end{array}$ & 1 & 10.07 & 0.39 & 0.548 \\
\hline
\end{tabular}


Although predators do not actively select autotomised prey (Downes and Shine 2001; own data) and even avoid them due to their smaller body size (Padilla et al. 2007), the risk of predation of tailless lizards may be high (Downes and Shine 2001). Tailless lizards cannot use caudal autotomy during encounters with predators (Kelehear and Webb 2006). Increasing vulnerability of lizards to predation could be caused, at least in part, by the impairment of locomotor performance (Chapple and Swain 2002). Hence, autotomised lizards change their anti-predator behaviour (Downes and Shine 2001; Cooper 2007). In our study, most autotomised individuals had regenerated tails. It is presumed that lizards with regenerated tails have gained experience during the previous predator contact and modified their behaviour when encountering the potential predator (in this case a human) for the second time. Due to this experience, such individuals may run faster (Brown et al. 1995). Kelehear and Webb (2006) showed that lizards, both autotomised and with intact tails, made more pauses when chased on a racetrack after a week, which was probably due to reencounter with the human "predator".

Some authors have shown that tail autotomy may reduce lizard running speed but only for a few weeks (Downes and Shine 2001; Chapple and Swain 2002). This suggests that tail autotomy may only temporarily affect locomotor ability. However, in the present study, there were no differences in running speed between lizards with regenerated tails and those with fresh caudal autotomy. This may suggest that in our study, lizards achieved faster speeds for longer, which may confirm a changing behaviour gained from experience. Alternatively, individuals that run faster, more often escape from predators and gain a better chance of survival. Hence, it is possible that the captured lizards with autotomy ran faster than those previously caught by predators.

Unexpectedly, we did not find any effect of tick presence and load on locomotor performance. Our results are in contrast with previous research, where lizards parasited by ticks ran slower than uninfected individuals of T. rugosa (Main and Bull 2000). It is known that lizards do not usually use their maximal locomotor ability (Hertz et al. 1988). Accordingly, both intact and autotomised sand lizards may not use their maximal locomotor ability, thus their physiological traits, even if changed by ticks or tickborne pathogens, might not have influenced their mean speed. Moreover, L. agilis has longer legs in relation to body length than $T$. rugosa; hence, the effect of tick load on the mechanics of movements may be different. Ticks may influence traits other than average speed, which are related to locomotor performance. In a previous study, it was suggested that Aponomma hydrosauri and Amblyomma limbatum ticks decreased endurance in Australian sleepy lizard, T. rugosa (Main and Bull 2000).
Predation and parasites are regarded as major biological factors influencing survival of animals. In the present study, we have shown that caudal autotomy had a bigger influence on lizard speed than ticks. Some authors suggest that predation risk may be assessed by investigating tail losses (Clobert et al. 2000; Diego-Rasilla 2003). Autotomy of brown anoles (Anolis sagrei) influenced predator frequency, predator efficiency and prey behaviour (Bateman and Fleming 2011). Hence, our results suggest that predator pressure may cause changes in L. agilis behaviour, namely locomotor performance, and, consequently, modify their escape ability.

This is the first time when running speed has been assessed using wild caught lizards, almost immediately after catching them in the field. Moreover, to the best of our knowledge, this is the first time the influence of ticks and autotomy on running speed in L. agilis has been studied.

Acknowledgments The authors would like to thank Prof. Tim Sparks and Dr. Sophie Madeja who has critically read the manuscript. This work was supported by grants NN 304381338 from the ministry of science and higher education of Poland and "PARENT-BRIDGE programme: support for women"-foundation for Polish science. A.E.G. is a scholarship holder within the project "scholarship support for Ph.D. students specialising in major strategic for the development of the Wielkopolska region of Poland", Sub-measure 8.2.2 human capital operational programme, co-financed by European Union under the European social fund. All procedures were carried out according to Polish law and the ethical commission for study on animals (LKE 12/2007 and 32/2011). The authors declare that they have no conflict of interest.

Open Access This article is distributed under the terms of the Creative Commons Attribution License which permits any use, distribution, and reproduction in any medium, provided the original author(s) and the source are credited.

\section{References}

Antczak M, Hromada M, Grzybek J, Tryjanowski P (2004) Breeding biology of the great grey shrike Lanius excubitor in W Poland. Acta Ornithol 39:9-14. doi:10.3161/0001645044214018

Arnold EN (1988) Caudal autotomy as a defence. In: Gans C, Huey R (eds) Biology of the Reptilia. Alan R Liss, New York, pp 235-273

Barnard SM, Durden LA (2000) A veterinary guide to the parasites of reptiles. Arthropods (excluding mites), Krieger Publishing Co, Malabar, Florida, No 2

Bateman PW, Fleming PA (2009) To cut a long tail short: a review of lizard caudal autotomy studies carried out over the last 20 years. J Zool (Lond) 277:1-14. doi:10.1111/j.1469-7998.2008.00484.x

Bateman PW, Fleming PA (2011) Frequency of tail loss reflects variation in predation levels, predator efficiency and the behaviour of three populations of brown anoles. Biol J Linn Soc 103:648-656

Bauwens D, Strijbosch H, Stumpel AHP (1983) The lizards Lacerta agilis and L. vivipara as hosts to larvae and nymphs of the tick Ixodes ricinus. Holarct Ecol 6:32-40. doi:10.1111/j.16000587.1983.tb01062.x

Bischoff W (1984) Lacerta agilis Linnaeus, 1758, Zauneidechse. In: B hme W (ed) Handbuch der Reptilien und Amphibien Europas. Aula Verlag, Germany, pp 23-68 
Bouma MJ, Smallridge CJ, Bull CM, Komdeur J (2007) Susceptibility to infection by a haemogregarine parasite and the impact of infection in the Australian sleepy lizard Tiliqua rugosa. Parasitol Res 100:949-954. doi:10.1007/s00436-006-0379-5

Brown RM, Taylor DH, Gist DH (1995) Effect of caudal autotomy on locomotor performance of wall lizards (Podarcis muralis). J Herpetol 29:98-105

Bull CM, Burzacott D (1993) The impact of tick load on the fitness of their lizard hosts. Oecologia 96:415-419. doi:10.1007/ BF00317513

Chapple DG, Swain R (2002) Effect of caudal autotomy on locomotor performance in a viviparous skink, Niveoscincus metallicus. Funct Ecol 16:817-825. doi:10.1046/j.1365-2435.2002.00687.x

Chapple DG, McCoull CJ, Swain R (2004) Effect of tail loss on sprint speed and growth in newborn skinks, Niveoscincus metallicus. J Herpetol 38:137-140. doi:10.1670/128-03N

Clobert J, Oppliger A, Sorci G, Ernande B, Swallow JG, Garland T Jr (2000) Trade-offs in phenotypic traits: endurance at birth, growth, survival, predation and susceptibility to parasitism in a lizard, Lacerta vivipara. Funct Ecol 14:675-684. doi:10.1046/j.13652435.2000.00477.x

Cooper WE Jr (2007) Compensatory changes in escape and refuge use following autotomy in the lizard Sceloporus virgatus. Can J Zool 85:99-107. doi:10.1139/z06-200

Cooper WE Jr, Vitt LJ, Hedges R, Huey RB (1990) Locomotor impairment and defence in gravid lizards (Eumeces laticeps): Behavioural shift in activity may offset costs of reproduction in an active forager. Behav Ecol Sociobiol 27:153-157. doi:10.1007/ BF00180298

Cooper WE Jr, Wilson DS, Smith GR (2009) Sex, reproductive status and cost of tail autotomy via decreased running speed in lizards. Ethology 115:7-13. doi:10.1111/j.1439-0310.2008.01575.x

Daniels CB (1983) Running: an escape strategy enhanced by autotomy. Herpetologica 39:162-165

Dial BE, Fitzpatrick LC (1984) Predator escape success in tailed versus tailless Scincella lateralis (Sauria: Scincidae). Anim Behav 32:301-302

Diego-Rasilla FJ (2003) Influence of predation pressure on the escape behaviour of Podarcis muralis lizards. Beha. Processes 63:1-7. doi:10.1016/S0376-6357(03)00026-3

Doughty P, Shine R, Lee MSY (2003) Energetic costs of tail loss in a montane scincid lizard. Comp Biochem Physiol A 135:215-219. doi:10.1016/S1095-6433(03)00087-4

Downes S, Shine R (2001) Why does tail loss increase a lizard's later vulnerability to snake predators? Ecology 82:1293-1303. doi:10.1890/0012-9658(2001) 082

Du W, Lin Z, Shou L, Ji X (2005) Morphological correlates of locomotor performance in four species of lizards using different habitats. Zoological Research 26:41-46

Dumler JS, Barbet AF, Bekker CPJ, Dasch GA, Palmer GH, Ray SC, Rikihisa Y, Rurangirwa FR (2001) Reorganisation of genera in the families Rickettsiaceae and Anaplasmataceae in the order Rickettsiales: unification of some species of Ehrlichia with Anaplasma, Cowdria with Ehrlichia and Ehrlichia with Neorickettsia, descriptions of six new species combinations and designation of Ehrlichia equi and "HGE agent" as subjective synonymus of Ehrlichia phagocytophila. Int J Syst Evol Microbiol 51:2145-2165. doi:10.1099/00207713-51-6-2145

Ekner A, Majlath I, Majlathova V, Hromada M, Bona M, Antczak M, Bogaczyk M, Tryjanowski P (2008) Densities and morphology of two co-existing lizard species (Lacerta agilis and Zootoca vivipara) in extensively used farmland in Poland. Folia Biol 56:165171. doi: $10.3409 / \mathrm{fb} .56$ 3-4.165-171

Ekner A, Dudek K, Sajkowska Z, Majlathova V, Majlath I, Tryjanowski P (2011) Anaplasmataceae and Borrelia burgendorferi sensu lato in the sand lizard Lacerta agilis and co-infection of these bacteria in hosted Ixodes ricinus ticks. Parasit Vectors 4:182. doi:10.1186/ 1756-3305-4-182

Farley CT (1997) Maximum speed and mechanical power output in lizards. J Exp Biol 200:2189-2195

Fenner AL, Bull CM (2008) The impact of nematode parasites on the behaviour of an Australian lizard, the gidgee skink Egernia stokesii. Ecol Res 23:897-903. doi:10.1007/s11284-007-0453-1

Fox SF, Heger NA, Delay LS (1990) Social cost of tail loss in Uta stansburiana: lizard tails as status-signalling badges. Anim Behav 39:549-554. doi:10.1016/S0003-3472(05)80421-X

Garland T Jr (1985) Ontogenetic and individual variation in size, shape and speed in the Australian agamid lizard Amphibolurus nuchalis. J Zool (London) 207:425-439. doi:10.1111/ j.1469-7998.1985.tb04941.x

Hertz PE, Huey RB, Garland T (1988) Time budgets, thermoregulation and maximal locomotor performance: are reptiles Olympians or boy scouts? Am Zool 28:927-938. doi:10.1093/icb/28.3.927

Huey RB, Dunham AE, Overall KL, Newman RA (1990) Variation in locomotor performance in demographically known populations of the lizard Sceloporus merriami. Physiol Zool 63:845-872

Husak JF (2006) Does survival depend on how fast you can run or how fast you do run? Funct Ecol 20:1080-1086. doi:10.1111/j.13652435.2006.01195.x

Jayne BC, Bennett AF (1990) Selection on locomotor performance capacity in a natural population of garter snake. Evolution 44:1204-1229

Juszczyk W (1987) Reptiles. In: Burg I (ed) Amphibians and reptiles of Poland. PWN, Warsaw, p 44 (in Polish)

Kelehear C, Webb JK (2006) Effects of tail autotomy on anti-predator behaviour and locomotor performance in a nocturnal gecko. Copeia 2006:803-809. doi:10.1643/0045-8511(2006) 6

Lavoie JP, Drolet R, Parsons D, Leguillette R, Sauvageau R, Shapiro J, Houle L, Hallè G, Gebhart CJ (2000) Equine proliferative enteropathy: a cause of weight loss, colic, diarrhoea and hypoproteinaemia in foals on three breeding farms in Canada. Equine Vet $\mathrm{J}$ 32:418-425. doi:10.2746/042516400777591110

Lehmann T (1993) Ectoparasitism: direct impact on host fitness. Parasitol Today 9:8-13. doi:10.1016/0169-4758(93)90153-7

Li C, Lian X, Bi J, Fang H, Maul TL, Jiang Z (2011) Effects of sand grain size and morphological traits on running speed of toadheaded lizard Phrynocephalus frontalis. J Arid Environ 75:1038-1042. doi:10.1016/j.jaridenv.2011.06.015

Lin Z-H, Ji X (2005) Partial tail loss has no severe effects on energy stores and locomotor performance in a lacertid lizard, Takydromus septentrionalis. J Comp Physiol B 175:567-573. doi:10.1007/s00360-005-0017-z

Lu H-L, Ding G-H, Ding P, Ji X (2010) Tail autotomy plays no important role in influencing locomotor performance and antipredator behaviour in a cursorial gecko. Ethology 116:627-634. doi:10.1111/j.1439-0310.2010.01780.x

Main AR, Bull CM (2000) The impact of tick parasites on the behaviour of the lizard Tiliqua rugosa. Oecologia 122:574-581. doi:10.1007/s004420050981

Martin J, Avery RA (1998) Effects of tail loss on the movement patterns of the lizard, Psammodromus algirus. Funct Ecol 12:794-802. doi:10.1046/j.1365-2435.1998.00247.x

Martín J, Salvador A (1993) Tail loss reduces mating success in the Iberian rock-lizard, Lacerta monticola. Behav Ecol Sociobiol 32:185-189. doi:10.1007/BF00173776

Martín J, Amo L, López P (2008) Parasites and health affect multiple sexual signals in male common wall lizards, Podarcis muralis. Naturwissenschaften 95:293-300. doi:10.1007/s00114-007-0328-x

Medger K, Verburgt L, Bateman PW (2008) The influence of tail autotomy on the escape response of the cape dwarf gecko, Lygodactylus capensis. Ethology 114:42-52. doi:10.1111/j.14390310.2007.01445.x

Møller AP (1990) Effect of parasitism by a haematophagus mite on reproduction in the Barn Swallow. Ecology 71:2345-2357 
Møller AP (1997) Parasitism and the evolution of host life history. In: Clayton DH, Moore J (eds) Host-parasite evolution: general principles and avian models. Oxford University Press, Oxford, pp $105-127$

Nemes S (2002) Foraging mode of the sand lizard, Lacerta agilis, at the beginning of its yearly activity period. Russ J Herpetol 9:5762

Oppliger A, Célérier ML, Clobert J (1996) Physiological and behaviour changes in common lizards parasitized by haemogregarines. Parasitology 113:433-438. doi:10.1017/S003118200008149x

Padilla DP, Nogales M, Marrero P (2007) Prey size selection of insular lizards by two sympatric predatory bird species. Acta Ornithol 42:167-172. doi:10.3161/000164507783516836

Pérez-Tris J, Díaz JA, Telleíra JL (2004) Loss of body mass under predation risk: cost of antipredatory behaviour or adaptive fit-for-escape? Anim Behav 67:511-521. doi:10.1016/j.anbehav.2003.06.008

Reavis RH, Barrett MA (2001) Do parasites affect the behaviour of the Hawaiian white-spotted toby, Canthigaster jactator (Pisces)? Acta Ethol 3:151-154. doi:10.1007/s102110000036

Salvador A, Martin J, Lopez P (1995) Tail loss reduces home range size and access to females in male lizards, Psammodromus algirus. Behav Ecol 6:382-387. doi:10.1093/beheco/6.4.382

Schall JJ (1990) Virulence of lizard malaria: the evolutionary ecology of an ancient parasite-host association. Parasitology 100:35-52. doi:10.1017/S0031182000073005

Schall JJ, Bennett AF, Putnam RW (1982) Lizards infected with malaria: physiological and behavioural consequences. Science 217:1057-1059

Shine R (2003) Locomotor speeds of gravid lizards: placing 'costs of reproduction' within an ecological context. Funct Ecol 17:526533. doi:10.1046/j.1365-2435.2003.00756.x

Siuda K (1993) Ticks (Acari: Ixodida) of Poland. Taxonomy and Distribution. Polish Parasitological Society No 2 (in Polish), Warsaw
Sorci G, Massot M, Clobert J (1994) Maternal parasite load increases sprint speed and philopatry in female offspring of the common lizard. Am Nat 144:153-164

Sorci G, Clobert J, Michalakis Y (1996) Cost of reproduction and cost of parasitism in the common lizard, Lacerta vivipara. Oikos 76:121-130

Sura P (2003) Sand lizard Lacerta agilis Linnaeus, 1758. In: Głowaciński Z, Rafiński J (eds) Atlas of the amphibians and reptiles of Poland. Status-Distribution-Conservation. Biblioteka Monitoringu Środowiska, Warszawa-Krakow, pp 84-86

Svetina C, Bart WB, Rastogi R, Hilton E (1999) The neuropsychological examination of naming in lyme borreliosis. Appl Neuropsychol 6:33-38. doi:10.1207/s15324826an0601 5

Tsuji JS, Huey RB, Van Berkum FH, Garland T Jr, Shaw RG (1989) Locomotor performance of hatchling fence lizards (Sceloporus occidentalis): quantitative genetics and morphometric correlates. Evol Ecol 3:240-252

Van Damme R, Vanhooydonck B (2001) Origins of interspecific variation in lizard sprint capacity. Funct Ecol 15:186-202. doi:10.1046/ j.1365-2435.2001.00513.x

Vanhooydonck B, Van Damme R (2003) Relationships between locomotor performance, microhabitat use and antipredator behaviour in lacertid lizards. Funct Ecol 17:276-281. doi:10.1046/j.13652435.2003.00716.x

Vervust B, Lailvaux SP, Grbac I, Van Damme R (2008) Do morphological condition indices predict locomotor performance in the lizard Podarcis sicula? Acta oecol 34:244-251. doi:10.1016/ j.actao.2008.05.012

Wikelski M (1999) Influences of parasites and thermoregulation on grouping tendencies in marine iguanas. Behav Ecol 10:22-29. doi:10.1093/beheco/10.1.22

Wilson BS (1992) Tail injuries increase the risk of mortality in freeliving lizards (Uta stansburiana). Oecologia 92:145-152. doi:10.1007/BF00317275 